\title{
A study of the protein requirements of the mature breeding ewe
}

\author{
Maintenance requirement of the non-pregnant ewe
}

\author{
BY J. J. ROBINSON AND T. J. FORBES \\ Agricultural Research Institute of Northern Ireland, Hillsborough and \\ The Queen's University of Belfast
}

(Received 9 August 1965-Accepted 31 December 1965)

\begin{abstract}
I. An experiment was carried out to study more precisely by nitrogen balance techniques the intake of digestible crude protein required for maintenance in the mature non-pregnant ewe, 2. Four isocaloric diets supplying adequate energy, approximately $90 \mathrm{kcal} / \mathrm{kg} W^{0.73} \mathrm{meta}$ bolizable energy daily, and differing in crude protein content were each given to eight individually penned ewes. The diets provided $2 \cdot 4,4 \cdot 9,7 \cdot 7$ and $9.5 \mathrm{~g}$ digestible $\mathrm{N}$ per ewe per day. 3. The average weight of the ewes was $57.4 \mathrm{~kg}$. They were rationed according to metabolic body-weight $\left(W^{0.73}\right)$ at a rate of approximately $800 \mathrm{~g}$ dry matter per $50 \mathrm{~kg}$ ewe per day for a 4-week period before $\mathrm{N}$ balance studies were carried out over an 8-day collection period. 4. The mean apparent digestibilities of dry matter were $67 \cdot 3 \pm 0.8,68 \cdot 1 \pm 0.7,70 \cdot 9 \pm 1 \cdot 0$ and $68.8 \pm 0.8$ respectively. The apparent digestibilities of $N$, increasing with increasing $N$ intake, were $30 \cdot 6 \pm 2 \cdot \mathrm{I}, 46 \cdot 3 \pm 2 \cdot \mathrm{I}, 58 \cdot 2 \pm 0 \cdot 6$ and $6 \mathrm{I} \cdot 5 \pm \mathrm{I} \cdot 3$ respectively. 5 . The intake of apparently digested $\mathrm{N}$ required for maintenance was calculated in three ways, from the regressions of apparently digested $\mathrm{N}$ on $\mathrm{N}$ retention or on urinary $\mathrm{N}$ and from the underlying relationship between $\mathrm{N}$ retention and urinary $\mathrm{N}$. The estimates so obtained were respectively $0.185 \pm 0.037$, $0.148 \pm 0.020$ and $0.150 \pm 0.020 \mathrm{~g} \mathrm{~N}$ per $\mathrm{kg} W^{0.73}$ per day, corresponding to $\mathrm{I} \cdot \mathrm{I} 6,0.93$ and $0.94 \mathrm{~g}$ apparently digestible crude protein per $\mathrm{kg} W^{0.78}$ per day. 6. Metabolic faecal $\mathrm{N}$, determined by the extrapolation method, was $0.629 \pm 0.047 \mathrm{~g} / \mathrm{r} 00 \mathrm{~g}$ dry matter consumed. 7. The results are discussed in relation to practical feeding standards and other research findings.
\end{abstract}

It has been accepted for some years that approximately $120 \mathrm{~g}$ digestible crude protein daily is necessary to meet the nitrogen requirements of the pregnant ewe during the later stages of gestation, and a requirement of approximately half this level has been suggested for the non-pregnant ewe (Phillipson, I959; Thomson \& Aitken, 1959). Brody (1945), in a comprehensive study of the $\mathrm{N}$ requirement of different species, indicated that the maintenance requirement of non-pregnant sheep was of the order of $3^{\cdot 6} \mathrm{~g}$ digestible crude protein $/ \mathrm{kg} W^{0 \cdot 73}$ daily. This corresponds to an intake of approximately $60 \mathrm{~g}$ digestible crude protein/day for a $50 \mathrm{~kg}$ ewe and is similar to the (USA) National Research Council (I957) recommendation of approximately $54 \mathrm{~g}$ digestible crude protein for ewes of the same weight.

There is, however, evidence that the maintenance requirement for protein may be much lower than these levels suggest. The results of Harris \& Mitchell (I94I) and those of Klein, Schmid, Studt \& Müller (I939; quoted by Harris \& Mitchell) show that approximately $23 \mathrm{~g}$ digestible crude protein daily may be adequate for the $50 \mathrm{~kg}$ non-pregnant ewe. Work at this Institute (Robinson \& Forbes, 1963, unpublished) has shown that pregnant ewes will remain in positive $\mathrm{N}$ balance during late gestation on a daily intake of digestible crude protein as low as $70 \mathrm{~g}$. These findings together 
with the diverse levels reported by other workers prompted us to re-investigate the $\mathrm{N}$ requirement of the mature non-pregnant ewe.

An experiment was planned during the summer of 1964 which aimed to determine more precisely, by $\mathrm{N}$ balance techniques and adequate replication, the intake of digestible crude protein that corresponds to zero $\mathrm{N}$ retention. Since it was important to define the zone of zero retention as accurately as possible, it was decided that several levels of $\mathrm{N}$ intake should be used giving if possible equally spaced digestible $\mathrm{N}$ intakes, distributed above and below zero retention. It was considered that this method was more accurate than extrapolating back to zero $\mathrm{N}$ retention from values obtained with positive $\mathrm{N}$ balances. The equal spacing was intended to give additional information on the pattern of $\mathrm{N}$ utilization at high and low levels of intake. The findings of Chalmers, Cuthbertson \& Synge (1954) and the levels discussed by Phillipson (1959) suggest that ewes would be in negative $\mathrm{N}$ balance on intakes of approximately $5 \mathrm{~g}$ and in positive balance on intakes of approximately $9 \mathrm{~g}$ of digestible $\mathrm{N}$ daily. It was decided therefore that four levels of crude protein intake should be used in this experiment and that these should supply 2-10 $\mathrm{g}$ of digestible $\mathrm{N}$ per day.

\section{EXPERIMENTAL}

Thirty-two non-pregnant Border Leicester $\times$ Scottish Blackface ewes aged between 3 and 4 years were used for the experiment. They were selected from a commercial suckling flock. The ewes were allocated to groups of four, balanced as near as possible for weight and stage of lactation (12 weeks); only ewes suckling twins were used.

Diets. The ewes were brought indoors as soon as the lambs had been removed and fed $a d l i b$. on a standard diet of medium-quality hay for $2-3$ weeks to terminate milk production and provide a uniform pre-experimental feeding treatment. After this preliminary period, the four ewes in each group were allocated at random to the following dietary treatments:

$\begin{array}{ccc}\text { Treatment } & \begin{array}{c}\text { Approximate daily } \\ \text { contribution of } \\ \text { apparently digestible } \\ \text { no. }\end{array} & \begin{array}{c}\text { Crude protein } \\ \text { content }(\%)\end{array} \\ \text { I } & 5.2 & \text { (g) ewe } \\ 2 & 6.8 & 2.5 \\ 3 & 8.6 & 5.0 \\ 4 & 9.7 & 7.5 \\ & & 10.0\end{array}$

In order to obtain the lowest $\mathrm{N}$ intake and maintain an equal and adequate energy intake on all treatments, it was necessary to use a proportion of maize starch in each diet. The hay was mature and of low nutritive value and was given in a chopped form to avoid wastage. The increasing crude protein contents were achieved by gradually replacing the flaked maize with soya-bean meal, while maintaining the energy content of the diets.

The daily dry-matter intake on each treatment was standardized at approximately $800 \mathrm{~g} / \mathrm{ewe}$ of $50 \mathrm{~kg}$ body-weight. The intakes of ewes above or below $5^{\circ} \mathrm{kg}$ live weight were adjusted on the basis of metabolic body-weight. In order that energy should not 
be a limiting factor, the diets were compounded to supply approximately $90 \mathrm{kcal}$ metabolizable energy $/ \mathrm{kg} W^{0.73}$ daily on each treatment, where $W=$ body-weight. This was considered adequate for maintenance and was based on the findings of Marston (1948) and Blaxter (1962a). Marston (1948) calculated a maintenance energy requirement of $88 \mathrm{kcal} / \mathrm{kg} W^{0.73}$ from energy balance experiments. Blaxter (Ig62a) determined the fasting energy metabolism and if this value is multiplied by the factor I.36 (Blaxter, 1962b) a requirement of $79 \mathrm{kcal} / \mathrm{kg} W^{0.73}$ is obtained for maintenance.

In view of the findings of Armstrong, Blaxter \& Graham (1957) it seemed likely that $\mathrm{N}$ utilization would be affected by the fibre content and the ratio of roughage to concentrate of the diet. It was therefore necessary to standardize the ratio of roughage to concentrate between treatments, and a ratio of approximately $I: I$ was adopted. The diets were also adjusted to give as nearly as possible an equal fibre intake of $\mathrm{I} 8 \cdot 0 \mathrm{~g} / \mathrm{ro0} \mathrm{g}$ feed intake on all treatments.

Management. The ewes were penned individually and given daily equal feeds at $9.00 \mathrm{am}$ and $5.00 \mathrm{pm}$. The hay and concentrates were given separately and the amount in $\mathrm{g}$ of air-dry feed to be offered was obtained by multiplying $W \mathrm{~kg}^{0.73}$ by the factors $22 \cdot 0$ and $27 \cdot 5$ for concentrates and hay respectively. These factors were calculated and used as a convenient method of ensuring equal dry-matter intakes per unit $W^{0.73}$ and a uniform roughage to concentrate ratio between treatments. The diets were offered for a 4-week period before the beginning of the $\mathrm{N}$ balances. The long pre-balance feeding period was necessary to allow the body-weight of the animals to become stable and to minimize pretreatment dietary effects on the rumen flora.

$N$ balance. $\mathrm{N}$ balances were determined in crates similar in size and design to the individual pens occupied by the ewes. A separation technique was adopted which enabled the faeces and urine to be collected without the use of harness. In view of the observations of Reid \& Mills (I962) in Australia, this technique was developed at this Institute and was intended to reduce disturbance and stress to a minimum during the balance period.

Chemical analysis. The hay and concentrates were sampled for chemical analysis and weighed out in one operation at the beginning of each ro-day balance period. Faeces and urine were collected each morning just before feeding. Glacial acetic acid was used to prevent loss of $\mathrm{N}$ during urine collection. Urine volumes were measured immediately after collection and $10 \%$ of the daily output was retained. The daily samples were bulked for each ewe and stored until the end of the balance for analysis. A similar sampling procedure was adopted for the faeces except that the daily samples were stored separately at $o^{\circ}$, using a few drops of toluene as a bacteriostat.

At the end of each balance period the daily faeces samples for each ewe were bulked, thoroughly mixed and sampled for dry-matter and $\mathrm{N}$ determinations. $\mathrm{N}$ determinations were made on the fresh material by the macro-Kjeldahl method and the dry-matter content was determined by oven drying at $100^{\circ}$ for $24 \mathrm{~h}$. The bulked 8-day urine samples were thoroughly mixed and Io $\mathrm{ml}$ samples analysed for $\mathrm{N}$. All analyses were carried out in triplicate. The gross energies of the feed and faeces were determined by bomb calorimetry, and the metabolizable energy value of the diet was calculated using 
the correction factor suggested by Blaxter ( 1964$)$. The results were analysed statistically as a randomized block and means were compared by the multiple range test of Duncan (1955).

\section{RESULTS}

The composition, digestible crude protein and metabolizable energy content of the diets used are given in Table $\mathrm{I}$. The diets presented no problems in feeding and were taken readily by all the ewes in the experiment.

Table r. Composition of diets

Chopped hay (\%)

Flaked maize $(\%)$

Maize starch (\%)

Soya-bean meal $(\%)$

Mineral supplement* (lb/100 lb mix)

Vitamin supplement $\dagger(\mathrm{lb} / \mathrm{I} 00 \mathrm{lb} \mathrm{mix})$

Digestible crude protein content (\%)

Metabolizable energy content (kcal/g)

\begin{tabular}{cccc}
\multicolumn{4}{c}{ Treatment } \\
\hline $\mathbf{1}$ & 2 & 3 & 4 \\
55.6 & 55.6 & 55.6 & 55.6 \\
16.6 & 12.0 & 2.8 & - \\
27.8 & 27.8 & 31.4 & 31.4 \\
-2.5 & 4.6 & 10.2 & 13.0 \\
+0.25 & +2.5 & +2.5 & +2.5 \\
1.59 & +0.25 & +0.25 & +0.25 \\
1.80 & 3.15 & 5.00 & 5.97 \\
& 1.78 & 1.88 & 1.84
\end{tabular}

* Declared composition: $\mathrm{P} 5.4 \%, \mathrm{Ca} 25.0 \%, \mathrm{NaCl} 25.0 \%, \mathrm{Fe} 0.3 \%, \mathrm{Mn} 1000 \mathrm{ppm}$, Co $100 \mathrm{ppm}$, I $200 \mathrm{ppm}$.

$\uparrow$ Declared composition: 800000 i.u. vitamin $\mathrm{A} / \mathrm{lb}$ and 200000 i.u. vitamin $\mathrm{D}_{3} / \mathrm{lb}$.

\section{Table 2. Nutrient intakes and digestibiltity}

(Mean values with their standard errors for eight ewes/treatment)

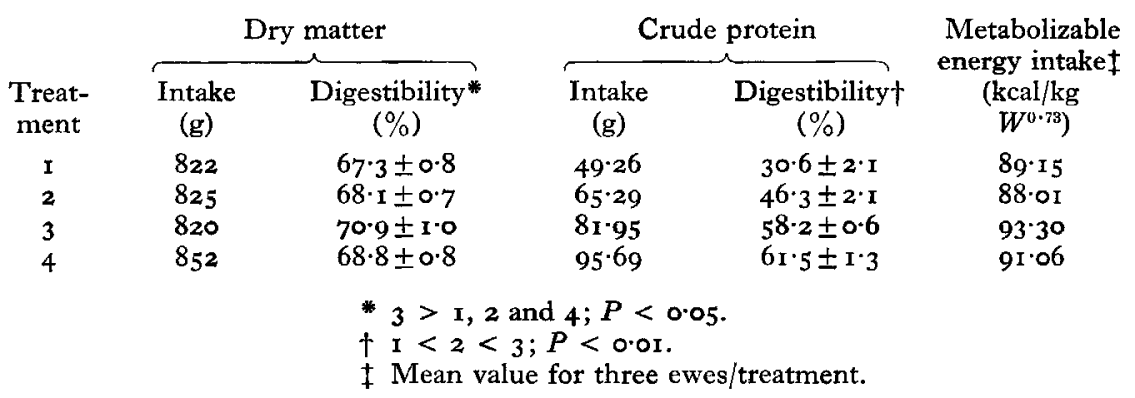

The values for mean nutrient intakes and digestibility are shown in Table 2. The mean intakes of dry matter with treatments $\mathbf{I}, \mathbf{2}$ and 3 were very similar but there was a slightly higher intake with treatment 4 . The mean digestibility of dry matter increased from treatment $\mathrm{I}$ to 3 , the digestibility with treatment 3 being significantly higher than with treatment $\mathrm{I}, 2$ or $4(P<0.05)$. The fall in digestibility with treatment 4 is difficult to explain, but may have been due to the slightly higher dry-matter intake with this treatment. The apparent digestibility of crude protein increased progressively with the increasing protein content of the diet. There was a significant difference $(P<0.01)$ between treatments 1,2 and 3 . The digestibility with treatment 4 was lower than expected, and although higher than with treatment 3 the difference was not significant. 
The mean live weight of ewes receiving each treatment, together with the mean intake, output and retention of $\mathrm{N}$, are given in Table 3. There was no significant difference in the mean live weights of ewes between treatments and no significant change in live weights during the balance period. The intakes of apparently digested $\mathrm{N}$ were very close to the planned levels except in treatment 4 in which the apparent digestibility of crude protein, $6 \mathrm{I} \cdot 5 \%$, was lower than expected for a diet containing approximately $10 \%$ crude protein. This rendered the overall values for apparently digested $\mathrm{N}$ unsuitable for orthogonal polynomial analysis as planned. The absolute levels of $\mathrm{N}$ retained with treatments I and 2 were higher than expected and thus the equal distribution of treatments above and below the maintenance point was not achieved. The increase in $\mathrm{N}$ retention between treatments 3 and 4 would indicate that the point of optimum $\mathrm{N}$ retention had not been reached in this experiment.

\section{Table 3. Nitrogen balance results (g/ezwe daily)}

(Mean values with their standard errors for eight ewes/treatment)

\begin{tabular}{|c|c|c|c|c|c|c|}
\hline reatment & $\begin{array}{c}\text { Ewe weight } \\
(\mathrm{kg})\end{array}$ & $\mathbf{N}$ intake & Faecal N & $\begin{array}{l}\text { Apparently } \\
\text { digested N }\end{array}$ & Urinary $\mathbf{N}$ & Retained N \\
\hline $\mathbf{I}$ & $57 \cdot 2 \pm 0.73$ & $7.82 \pm 0.07$ & $5.42 \pm 0.13$ & $2 \cdot 40 \pm 0.18$ & $2 \cdot 63 \pm 0.12$ & $-0.23 \pm 0.19$ \\
\hline 2 & $5^{8 \cdot 2} \pm \mathrm{I} \cdot 10$ & $10.49 \pm 0.15$ & $5.63 \pm 0.23$ & $4.86 \pm 0.25$ & $4.15 \pm 0.23$ & $+0.71 \pm 0.22$ \\
\hline 3 & $57 \cdot 3=$ & I $3.17 \pm 0.28$ & $5.50 \pm 0.16$ & $7.67 \pm 0.16$ & \pm 0.31 & $+\mathrm{r} \cdot 88 \pm 0.24$ \\
\hline 4 & $\pm I \cdot 50$ & $15.37 \pm 0.43$ & $5 \cdot 89 \pm 0.17$ & $9.4^{8} \pm 0.42$ & $6.87 \pm 0.43$ & $+2 \cdot 61 \pm 0.26$ \\
\hline
\end{tabular}

The intake of digestible crude protein required for maintenance in this experiment has been assessed by two methods: (I) calculating the level of digestible $\mathrm{N}$ intake which corresponds to zero $\mathrm{N}$ retention, and (2) calculating the level of digestible $\mathrm{N}$ intake which exactly balances urinary output. The values used in these calculations have been corrected for differences in body-weight between ewes.

In method I the maintenance requirement can be calculated from the regression of apparently digested $\mathrm{N}$ on $\mathrm{N}$ retained, as shown in Fig. I. A highly significant linear relationship was obtained giving the regression equation $y=2 \cdot 08 x+3.53$, where $x=$ the $\mathrm{N}$ retained and $y=$ the apparently digested $\mathrm{N}$ in $\mathrm{g} /$ day. The intercept on the $y$ axis represents the intake level at zero retention and gives a calculated maintenance requirement of $3.53 \pm 0.7 \mathrm{I} g$ apparently digested $\mathrm{N}$ per ewe per day. This corresponds to $0.185 \pm 0.037 \mathrm{~g}$ apparently digested $\mathrm{N}$, or $\mathrm{I} \cdot \mathrm{I} 6 \mathrm{~g}$ digestible crude protein $/ \mathrm{kg} W^{0.73}$. The overall efficiency of utilization of the apparently digested $\mathrm{N}$ is given by the reciprocal of the slope of the regression line and was $48.08 \%$. This compares favourably with efficiencies of 40 and $49 \%$ quoted by Mitchell (I962) for the utilization of the true digested $\mathrm{N}$ of urea and casein respectively. Since the values for apparently digested $\mathrm{N}$ used in our regression were based on equal dry-matter intakes between treatments, the regression is comparable with that of Mitchell (1962).

In method 2 the maintenance value can be calculated from the regression of apparently digested $\mathrm{N}$ on urinary $\mathrm{N}$, as shown in Fig. 2. Again a linear relationship was obtained giving the regression equation $y=1 \cdot 57 x-1 \cdot 62$, where $x=$ urinary $\mathrm{N}$ in $\mathrm{g} /$ day and $y=$ apparently digested $\mathrm{N}$ in $\mathrm{g} /$ day. The point at which the regression line 


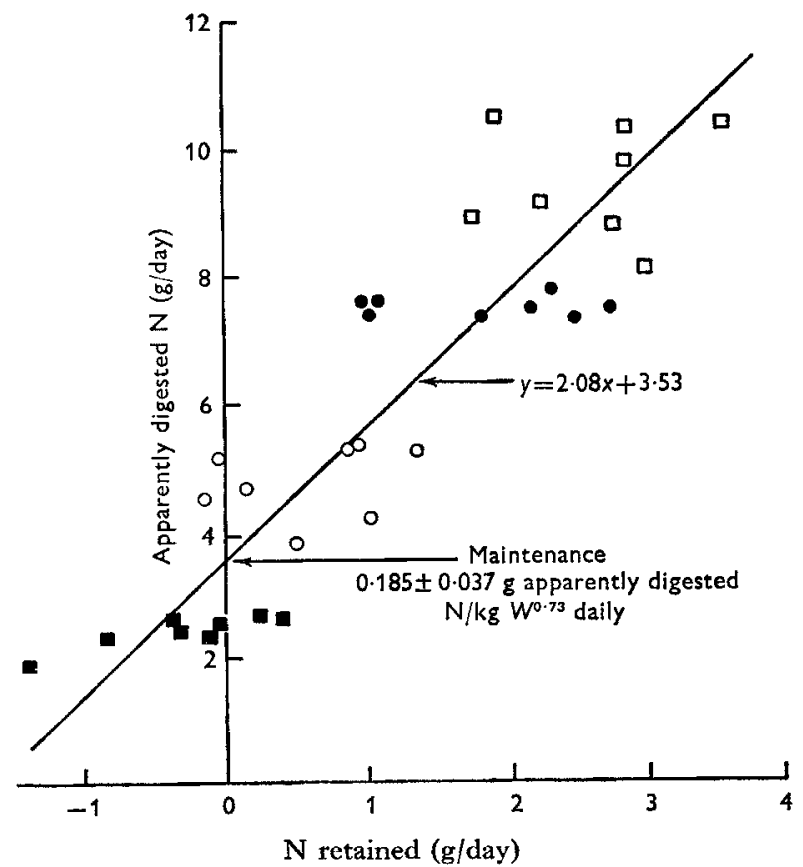

Fig. I. Relationship in ewes between apparently digested $N(y)$ and $N$ retained $(x)$. Values are shown for individual ewes receiving: 1 , treatment I; 0 , treatment 2 ; $\bullet$, treatment 3 ; $\square$, treatment 4 .

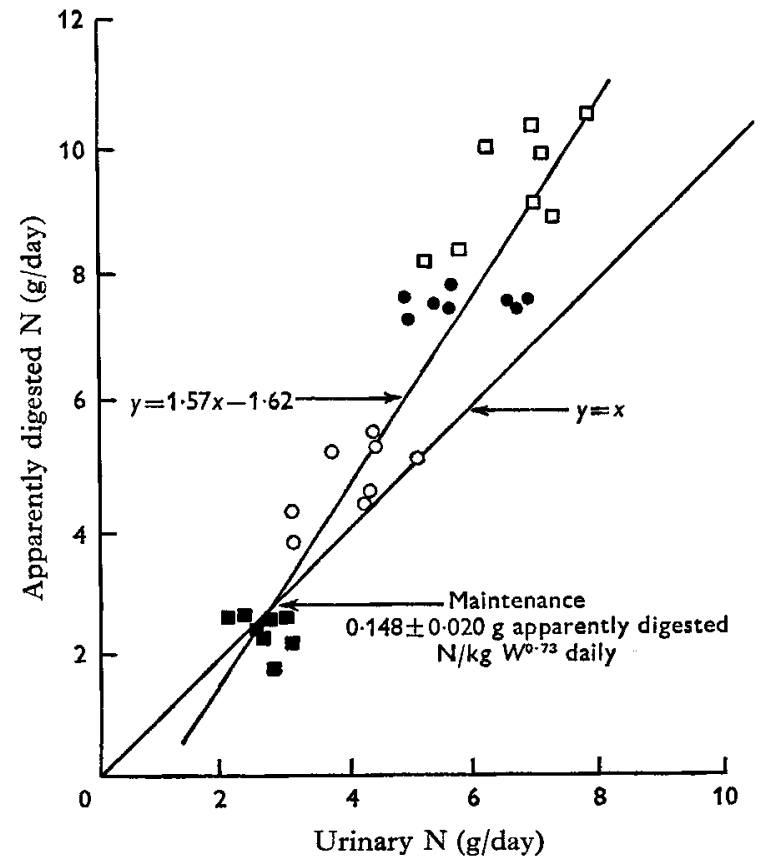

Fig. 2. Relationship in ewes between apparently digested $\mathrm{N}(y)$ and urinary $\mathrm{N}(x)$. Values are shown for individual ewes receiving: $\rightarrow$ treatment $I$; $O$, treatment 2 ; $\bullet$, treatment 3 ; $\square$, treatment 4 . 
cuts the line $y=x$ represents the apparently digested $\mathrm{N}$ required to balance urinary output and gives a calculated requirement of $2.84 \pm 0.38 \mathrm{~g}$ apparently digested $\mathrm{N}$ per ewe per day. This corresponds to $0.148 \pm 0.020 \mathrm{~g} \mathrm{~N}$, or $0.93 \mathrm{~g}$ protein $/ \mathrm{kg} W^{0.73}$ daily. These values are $20 \%$ lower than those obtained by method I. Elliott \& Topps (1964), using the same methods, found a difference of approximately $25 \%$ between the values obtained.

A highly significant linear correlation $(r=0.93)$ was obtained between the daily urinary $\mathrm{N}$ output and the amount of $\mathrm{N}$ consumed in the feed over the range of $\mathrm{N}$ intakes studied. The equation of the regression line was $y=0.567 x-\mathrm{I} \cdot 8 \mathrm{I}$, where $x$ and $y$ represent in $g$ the daily $N$ intake and daily urinary $N$ excretion respectively. The relationship between faecal $N$ per unit dry-matter intake and the percentage $N$ in the dry matter of the feed has been used to estimate the metabolic faecal N (Blaxter \& Mitchell, 1948). In this experiment the regression equation of this relationship was $y=0.033 x+0.629$, where $y=$ the faecal N expressed as a percentage of the drymatter intake and $x=$ the percentage $\mathrm{N}$ content of the dry matter of the feed. The intercept on the $y$ axis $(0.629 \pm 0.047)$ gives the metabolic faecal $\mathrm{N}$ in g/roo g dry matter consumed. This level is slightly lower than that reported by Sotola (I930), but higher than the values obtained by Hutchinson (1958), Harris \& Mitchell (194I) and Turk, Morrison \& Maynard (1934) which vary from 0.53 to $0.56 \mathrm{~g} \mathrm{~N} / \mathrm{ro0}$ g dry matter consumed on $\mathrm{N}$-free diets.

\section{DISCUSSION}

The recent work of Tagari, Dror, Ascarelli \& Bondi (1964) suggests that maize starch in the diet can increase the apparent digestibility of crude protein. Despite this, it is generally recognized that the addition of readily available carbohydrate can have an adverse effect on apparent digestibility of protein (Head, I953; Head \& Murdoch, I965). However, it was necessary to use readily available carbohydrate in the form of maize starch in this experiment to obtain equal and adequate intakes of energy and fibre and at the same time give the required difference in intakes of $\mathrm{N}$ between treatments. To reduce any possible interactions, the content of starch in the diets was kept as uniform as possible between treatments.

There was a significant increase in the apparent digestibility of crude protein with treatments $I_{1} 2$ and 3 , and attention is drawn to the very low apparent digestibilities with treatments $I$ and 2 . At the lower protein intakes a relatively higher proportion of intake is represented by the metabolic faecal $\mathrm{N}$. This has the effect of lowering the apparent digestibility at low protein intakes and emphasizes the importance of considering the metabolic faecal $\mathrm{N}$ in arriving at the protein requirement for maintenance. Because metabolic faecal $\mathrm{N}$ varies with feed intake there is in fact not a unique protein requirement in terms of apparently digestible protein. For a statement of protein requirement independent of feed intake it would be necessary to use 'available protein', as discussed by Blaxter ' $\&$ Mitchell (1948). In mature ewes Blaxter \& Mitchell (1948) have shown that the metabolic faecal N, expressed as protein, amounts to approximately $60 \%$ of the true digested protein required for maintenance. In this study the level of metabolic faecal protein was calculated at $3.93 \pm 0.28 \mathrm{~g} / \mathrm{100 \textrm {g }}$ 
dry matter consumed; this represents 60 and $66 \%$ of the maintenance requirement for protein, as true digested protein, calculated in this study. This is similar to the value of approximately $60 \%$ given by Blaxter \& Mitchell (1948). From the values given in Table $\mathrm{I}$ it is interesting to note that a diet containing approximately $2 \%$ apparently digested crude protein given at approximately $\mathrm{I} \mathrm{kg} /$ day is sufficient to maintain a $50 \mathrm{~kg}$ ewe in $\mathrm{N}$ balance provided the energy intake is adequate. However, owing to the low apparent digestibility with treatments $I$ and 2 this is equivalent to approximately $6 \%$ crude protein in a diet given at the same rate.

The higher $\mathrm{N}$ retention with the low $\mathrm{N}$ intakes compared, for example, with those obtained by Chalmers et al. (1954), was probably due to the higher energy intake in this experiment. The readily available carbohydrates also probably increased the efficiency of $\mathrm{N}$ utilization, as shown by McDonald (1952), Chalmers (196r), Lewis (1957) and Phillipson, Dobson, Blackburn \& Brown (1962). In view of the findings of Allison (1956), the possible effect of depleted protein reserves due to the immediately previous lactation cannot be overlooked.

The two estimates of maintenance requirements obtained in this experiment were $3 \cdot 53 \pm 0 \cdot 7 \mathrm{I}$ and $2 \cdot 84 \pm 0.38 \mathrm{~g}$ apparently digested $\mathrm{N}$ per ewe per day. These are only $3 \mathrm{I} \cdot 7$ and $25 \cdot 3 \%$ respectively of the level suggested by Brody ( 1945 ) and approximately one-third of the allowance recommended by the (USA) National Research Council (1957). They are, however, very similar to the values obtained by Harris \& Mitchell (194I) and Klein et al. (1939; as cited by Harris \& Mitchell). They are also very similar to the results reported by Elliott \& Topps (1964) after this experiment had commenced. Using diets with varying ratios of roughage to concentrate, Elliott \& Topps showed that the maintenance requirements for apparently digested crude protein increased with increasing proportions of roughage in the diet. The requirement calculated with a diet containing I part roughage to I part concentrate was only $23.8 \%$ of the allowance suggested by Brody (1945) and compares favourably with the $25.3 \%$ obtained in this experiment with a similar ratio of roughage to concentrate.

The lower standard error for the maintenance value obtained by method 2 may be attributed to the greater accuracy in obtaining urinary $\mathrm{N}$ by one straightforward analysis as compared with the errors in analysis of feed, faeces and urine in obtaining the $\mathrm{N}$ retention values used in method $\mathrm{I}$. The difference in the two estimates obtained for maintenance can be accounted for by the fact that method $I$ in effect uses the regression of urinary $\mathrm{N}$ on retained $\mathrm{N}$ and method 2 the regression of retained $\mathrm{N}$ on urinary N. Since the regression of $y$ on $x$ is not the same as that of $x$ on $y$ the two estimates are bound to differ. The best estimate for maintenance $\mathrm{N}$ will lie between these two values, and Langlands, Corbett, McDonald \& Pullar (1963) have shown in similar circumstances that this value can be determined by the calculation of the underlying or functional relationship between the two variates, given the relative precision with which each determination can be obtained. It was estimated that the error in determining $\mathrm{N}$ retention was approximately three times that in determining urinary $\mathbf{N}$. Using this ratio of $3: 1$, the functional relationship was calculated by the method outlined by Davies (1957). This gave the relationship $y=\mathrm{I} \cdot 67 x+2 \cdot 90$, where $x$ and $y$ represent, in $\mathrm{g} /$ day, the retained and urinary $\mathrm{N}$ 
respectively. At the point where retained $\mathrm{N}$ is zero the maintenance value in terms of digestible $\mathrm{N}$ is represented by the level of urinary $\mathrm{N}$ and gives the value $2 \cdot 90 \pm 0.39 \mathrm{~g}$ / day or $0.150 \pm 0.02 \mathrm{~g} / \mathrm{kg} W^{0.73}$.

The extrapolation of the regression between daily $\mathrm{N}$ intake and daily urinary $\mathrm{N}$ output to zero intake has been used to estimate endogenous urinary $\mathrm{N}$ by Elliott \& Topps (1963, 1964). The equation obtained in the present experiment was $y=0.567 x-\mathrm{I} \cdot 8 \mathrm{I}$ and gives a value of $-\mathrm{I} \cdot 8 \mathrm{I} \pm 0.50 \mathrm{~g}$ of endogenous urinary $\mathrm{N}$ per ewe daily. The negative value shows that the lowest level of intake of apparently digested $\mathrm{N}$, although only $2 \cdot 4 \mathrm{~g} /$ day, was not low enough to indicate the true response curve approaching the zone of zero $\mathrm{N}$ intake.

The unexpectedly high retention on treatment I may be accounted for by the relatively lower output of urinary $\mathrm{N}$. With treatment $\mathrm{I}$ the urinary $\mathrm{N}$ output represented $33.6 \%$ of the $\mathrm{N}$ intake compared with $39^{\circ} 6,44^{\circ} \mathrm{O}$ and $44.7 \%$ with treatments 2,3 and 4 respectively. This apparently continued lowering of $\mathrm{N}$ output with treatment $\mathrm{I}$, when the majority of ewes were in negative balance, may have been brought about by a recycling of urea into the rumen. The results of Schmidt-Nielsen \& Osaki (1958) and Somers ( $196 \mathrm{r}$ ) show that recycling can take place on low-protein diets. In addition, the recent work of Packett \& Groves (1965) suggests that urea recycling occurs most on low-protein diets containing readily available carbohydrate in the form of starch. Since the diets used in our experiment contained approximately $30 \%$ maize starch it seems very probable that urea recycling was taking place. With intakes of low protein the effect of urea recycling may be, therefore, of considerable practical significance in determining maintenance protein requirements; further investigation is required before the effect can be fully assessed.

The authors wish to thank the Director and Trustees of The Agricultural Research Institute of Northern Ireland for the facilities provided for this work. They also wish to thank Mr R. Watt for technical assistance.

\section{REFERENCES}

Allison, J. B. (1956). Am. J. clin. Nutr. 4, 662.

Armstrong, D. G., Blaxter, K. L. \& Graham, N. McC. (1957). Br. J. Nutr. II, 392.

Blaxter, K. L. (1962a). Br. F. Nutr. 16, 615.

Blaxter, K. L. (1962b). The Energy Metabolism of Ruminants, p. 233. London: Hutchinson.

Blaxter, K. L. (1964). Proc. Nutr. Soc. 23, 62.

Blaxter, K. L. \& Mitchell, H. H. (1948). F. Anim. Sci. 7, 35 r.

Brody, S. (r945). Bioenergetics and Growth. New York: Reinhold Publishing Corp.

Chalmers, M. I. (1961). In Digestive Physiology and Nutrition of the Ruminant, p. 205. [D. Lewis, editor.] London: Butterworths.

Chalmers, M. I., Cuthbertson, D. P. \& Synge, R. L. M. (1954). F. agric. Sci., Camb., 44, 254.

Davies, O. L. (1957). Statistical Methods in Research and Production, p. I73. London: Oliver and Boyd. Duncan, D. B. (I955). Biometrics, I $1, \mathbf{r}$.

Elliott, R. C. \& Topps, J. H. (1963). Br. F. Nutr. 17, 539.

Elliott, R. C. \& Topps, J. H. (1964). Br. F. Nutr. 18, 245.

Harris, L. E. \& Mitchell, H. H. (I94I). F. Nutr. 22, I67.

Head, M. J. (1953). Y. agric. Sci., Camb., 43, 281 .

Head, M. J. \& Murdoch, J. C. (1965). F. Br. Grassl. Soc. 2o, 106.

Hutchinson, K. J. (1958). Aust. F. agric. Res. 9, 508.

Langlands, J. P., Corbett, J. L., McDonald, I. \& Pullar, J. D. (1963). J. Anim. Prod. 5, I. 
Lewis, D. (1957). F. agric. Sci., Camb., 48, 438.

McDonald, I. W. (1952). Biochem. F. 51, 86.

Marston, H. R. (1 948). Aust. F. scient. Res. I, 93.

Mitchell, H. H. (1962). Comparative Nutrition of Man and Domestic Animals. Vol. I, p. 167. New York and London: Academic Press Inc.

National Research Council (1957). Publs natn. Res. Coun., Wash., no. 504.

Packett, L. V. \& Groves, T. D. D. (1965). F. Anim. Sci. 24, 341.

Phillipson, A. T. (1959). Scientific Principles of Feeding Farm Livestock, p. I17. London: Farmer and Stock-Breeder Publications Ltd.

Phillipson, A. T., Dobson, N. J., Blackburn, T. H. \& Brown, M. (1962). Br. J. Nutr. 16, I57.

Reid, R. L. \& Mills, S. C. (1962). Aust. F. agric. Res. 13, 282.

Schmidt-Nielsen, B. \& Osaki, H. (1958). Am. Y. Physiol. 193, 657.

Somers, M. (1961). Aust. F. exp. Biol. med. Sci. 39, 145.

Sotola, J. (1930). J. agric. Res. 40, 79.

Tagari, H., Dror, Y., Ascarelli, I. \& Bondi, A. (I964). Br. F. Nutr. 18, 333.

Thomson, W. \& Aitken, F. C. (1959). Tech. Commun. Commonw. Bur. Anim. Nutr. 20.

Turk, T. L., Morrison, F. B. \& Maynard, L. A. (1934). F. agric. Res. 48, 555. 